\title{
Pengembangan Model Matematika SIRD (Susceptibles- Infected-Recovery-Deaths) Pada Penyebaran Virus Ebola
}

\author{
Endah Purwati dan Sugiyanto \\ Program Studi Matematika, Fakultas Sains dan Teknologi, Universitas Islam Negeri Sunan Kalijaga \\ Yogyakarta, Jl. Marsda Adisucipto Yogyakarta 55281 \\ Korespondensi ditujukan kepada Sugiyanto; Email: sugimath@yahoo.com
}

\begin{abstract}
Abstrak
Ebola adalah penyakit mematikan yang disebabkan oleh virus dan ditularkan melalui kontak langsung dengan darah atau cairan tubuh seperti air seni, tinja, ASI, air liur dan air mani. Dalam hal ini, kontak langsung berarti bahwa darah atau cairan tubuh pasien langsung menyentuh hidung, mata, mulut, atau membuka luka seseorang. Dalam tulisan ini diperiksa dua model matematik SIRD (Susceptibles-Terinfeksi-Pemulihan-Death) penyebaran virus Ebola pada populasi manusia. Kedua model matematika SIRD terhadap penyebaran virus Ebola adalah model dengan Abdon Emile A. dan F. D. G. dan model pengembangan penelitian. Penelitian ini dilakukan untuk menentukan titik ekuilibrium bebas penyakit dan titik ekuilibrium endemik dan analisis stabilitas poin, mengetahui nilai jumlah dasar reproduksi (R0) dan model simulasi menggunakan software Matlab versi 6.1.0.450. Dari analisis dari dua model, diperoleh titik yang sama untuk bebas penyakit titik ekuilibrium dengan sudut pandang yang berbeda stabilitas dan berbagai tempat untuk titik ekuilibrium endemik dengan titik kedua stabilitas yang sama dan nilai yang sama dengan nilai reproduksi dasar jumlah (R0). Setelah model simulasi dengan menggunakan Matlab versi software 6.1.0.450, perubahan terlihat dalam perilaku penduduk setiap saat.
\end{abstract}

Kata Kunci: Model matematika SIRD; Virus Ebola; Titik Equilibrium; Titik Stabilitas Equilibrium; Dasar Nomor Reproduksi dan Model Simulasi.

\begin{abstract}
Ebola is a deadly disease caused by a virus and is spread through direct contact with blood or body fluids such as urine, feces, breast milk, saliva and semen. In this case, direct contact means that the blood or body fluids of patients were directly touching the nose, eyes, mouth, or a wound someone open. In this paper examined two mathematical models SIRD (Susceptibles-Infected-Recovery-Deaths) the spread of the Ebola virus in the human population. Both the mathematical model SIRD on the spread of the Ebola virus is a model by Abdon A. and Emile F. D. G. and research development model. This study was conducted to determine the point of disease-free equilibrium and endemic equilibrium point and stability analysis of the dots, knowing the value of the basic reproduction number (RO) and a simulation model using Matlab software version 6.1.0.450. From the analysis of the two models, obtained the same point for disease-free equilibrium point with the stability of different points and different points for endemic equilibrium point with the stability of both the same point and the same value to the value of the basic reproduction number (R0). After simulating the model using Matlab software version 6.1.0.450, it can be seen changes in the behavior of the population at any time.
\end{abstract}

Keywords: Mathematical Models SIRD; Ebola Virus; point Equilibrium; Stability Equilibrium point; the Basic Reproduction Number and Simulation Model.

\section{Pendahuluan}

Virus ebola adalah anggota dari keluarga virus filoviridae, virus dalam keluarga,yang disebut Filoviruses, menyebabkan demam berdarah yang parah pada manusia dan primata. Demam berdarah ditandai dengan demam tinggi, pendarahan internal, hipotensi dan shock. Ada Lima jenis yang dikenal dari virus ebola, yaitu ebola-zaire, ebola-sudan, ebola-ivory coast, ebola-bundibugyo dan ebolareston [Yarus, 2012].

Pada jurnal ini, penyebaran virus ebola dimodelkan dengan menggunakan model matematika $S / R D$ (Suscptibles-Infected-Recovery-Deaths). Populasi model dibagi menjadi 4 kelompok, yaitu kelompok $S$ 
(Populasi yang rentan terhadap penyakit), kelompok / (Populasi individu yang terinfeksi oleh virus ebola), kelompok $R$ (Populasi yang sembuh dari infeksi dan tidak kebal terhadap virus ebola), kelompok $D$ (Total kematian yang disebabkan oleh ebola atau kematian alami dan penyakit lainnya (selain ebola). Pada skripsi ini akan dibahas dua model, yaitu model SIRD pada penyebaran virus ebola oleh Abdon A. dan Emile F. D. G. dan model SIRD pada penyebaran virus ebola oleh peneliti. Analisis terhadap model SIRD pada penyebaran virus ebola dilakukan dengan menentukan titik ekuilibrium bebas penyakit dan titik ekilibrium endemik serta analisis kestabilannya, menentukan nilai basic reproduction number $\left(R_{0}\right)$ serta simulasi modelnya dengan software Matlab versi 6.1.0.450.

\section{Formulasi Model}

Pada Model kedua matematika SIRD pada penyebaran virus ebola, digunakan beberapa parameter yaitu $\alpha$ menyatakan peluang terbesar kematian yang disebabkan oleh kematian alami dan penyakit lainnya (selain ebola), $s$ menyatakan peluang terbesar kerentanan terhadap virus ebola, $i$ menyatakan peluang terbesar infeksi oleh virus ebola, $r$ menyatakan peluang terbesar pemulihan terhadap virus ebola dan $d$ menyatakan peluang terbesar kematian oleh virus ebola. Parameter $\alpha, s, i, r$ dan $d$ adalah konstanta-konstanta bernilai positif. Pada bab ini, akan dibahas dua model yaitu:

1. Model matematika SIRD pada penyebaran virus ebola dari penelitian yang dilakukan oleh Abdon A. dan Emile F. D. G. dalam penelitiannya yang berjudul On the Mathematical Analysis of Ebola Hemorrhagic Fever: Deathly Infection Disease in West African Countries .

2. Model matematika SIRD pada penyebaran virus ebola oleh peneliti.

Pada penelitian ini peneliti memodifikasi penelitian yang dilakukan oleh Abdon A. dan Emile F. D. G. dalam penelitiannya yang berjudul On the Mathematical Analysis of Ebola Hemorrhagic Fever: Deathly Infection Disease in West African Countries, karena orang yang sudah terinfeksi oleh virus ebola, peluang terbesar akan mati karena virus ebola, dan yang mati karena kematian alami dan penyakit lainnya (selain ebola) peluangnya sangat sedikit. Dalam penelitian ini, peneliti memberikan alternatif model matematika SIRD pada penyebaran virus ebola, dengan asumsi seseorang yang sudah terinfeksi oleh virus ebola yang mati, orang tersebut mati karena penyakit ebola dan kematian yang disebabkan oleh kematian alami dan penyakit lainnya (selain ebola) hanya terjadi pada populasi individu rentan.

\section{Pembahasan}

Berikut akan dilakukan analisis yang sama pada kedua model matematika SIRD pada penyebaran virus ebola, diantaranya menentukan titik ekuilibrium bebas penyakit dan titik ekuilibrium endemik, menganalisis kestabilan kedua titik ekuilibrium, menentukan nilai basic reproduction number $\left(R_{0}\right)$ dan simulasi modelnya dengan menggunakan software Matlab versi 6.1.0.450.

Model matematika SIRD pada penyebaran virus ebola oleh Abdon A. dan Emile F. D. G

Untuk mempermudah dalam pemodelan penyebaran virus ebola ke dalam model matematika diperlukan asumsi-asumsi, yaitu populasi tertutup, individu yang lahir termasuk dalam populasi individu rentan, individu yang sembuh dari ebola tidak diberikan kekebalan, masa inkubasi diabaikan, setiap individu yang terjangkit akan menjadi terinfeksi, kematian alami dan kematian yang disebabkan oleh penyakit lain (selain ebola) terjadi pada populasi total $N$ di populasi individu rentan dan belum ditemukan vaksin.

Berdasarkan keterangan dan asumsi yang ada, dapat dibuat diagram alir model matematika penyebaran virus ebola, sebagai berikut: 


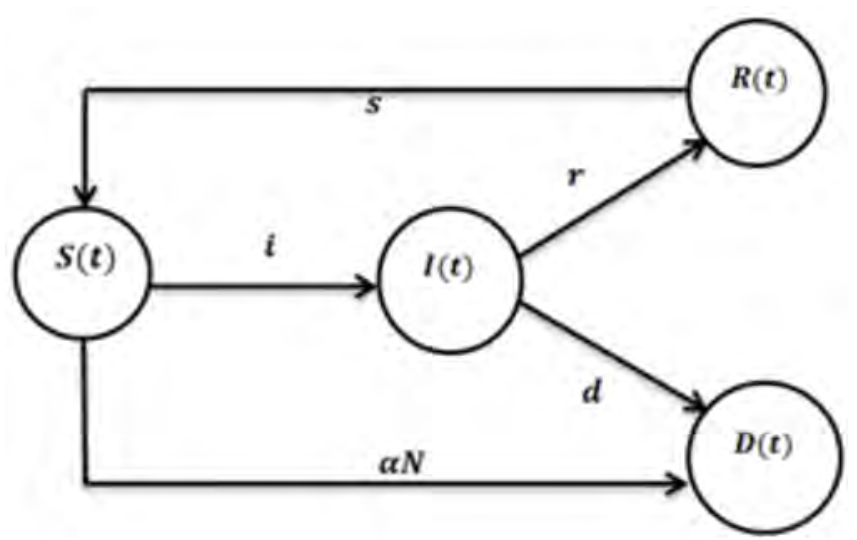

Gambar 1 Diagram alir model SIRD pada penyebaran virus ebola oleh Abdon A. dan Emile F. D. G.

\section{Interpretasi Diagram}

a. Populasi individu rentan

Populasi individu rentan yang terinfeksi virus ebola, akan menjadi populasi individu terinfeksi virus ebola. Populasi individu rentan bertambah karena adanya individu yang sembuh dari ebola, akan tetapi tidak mempunyai kekebalan terhadap ebola dan berkurang karena adanya individu yang terinfeksi virus ebola serta kematian alami dan kematian oleh penyakit lain (selain ebola) pada populasi total $N$. sehingga diperoleh persamaaan berikut:

$$
\frac{d(t)}{d}=-i^{\prime}(t) I(t)+s(t)-\alpha
$$

b. Populasi individu terinfeksi

Bertambahnya populasi terinfeksi ebola, karena individu yang rentan yang kontak langsung dengan penderita ebola. Berkurangnya populasi individu terinfeksi, dikarenakan individu yang sembuh karena kekebalan tubuh alami dan individu yang mati karena ebola, sehingga diperoleh persamaan berikut:

$$
\frac{d(t)}{d}=i_{1}^{\prime}(t) I(t)-r(t)-d(t)
$$

c. Populasi individu yang sembuh dan tidak kebal virus ebola

Populasi ini bertambah dari individu terinfeksi yang sembuh dan berkurang karena individu yang sembuh dari ebola tidak memiliki kekebalan terhadap virus ebola, sehingga akan menjadi individu rentan kembali. Populasi individu yang sembuh dan tidak kebal virus ebola diberikan oleh persamaan berikut:

$$
\frac{d(t)}{d}=r(t)-s(t)
$$

d. Populasi individu yang mati

Populasi individu yang mati disini tidak hanya berasal dari kematian yang disebabkan oleh virus ebola akan tetapi juga kematian yang disebabkan oleh kematian alami dan kematian yang disebabkan oleh penyakit lain (selain ebola) pada populasi total $N$, sehingga diperoleh persamaan berikut:

$$
\frac{d(t)}{d}=d(t)+\alpha
$$


Dari keempat persamaan diatas diperoleh sistem sebagai berikut:

$$
\begin{aligned}
& \frac{d(t)}{d}=-i_{:}^{\prime}(t) I(t)+s(t)-\alpha \\
& \frac{d(t)}{d}=i^{\prime}(t) I(t)-r(t)-d(t) \\
& \frac{d^{\prime}(t)}{d}=r(t)-s(t) \\
& \frac{d^{2}(t)}{d}=d(t)+\alpha
\end{aligned}
$$

\section{Titik Ekuilibrium}

Dalam keadaan setimbang $\frac{d S}{d t}=0, \frac{d I}{d t}=0, \frac{d R}{d t}=0$, dan $S(t)=S, I(t)=I, R(t)=R$ sehingga persamaan (5) dapat ditulis:

$$
\begin{aligned}
& -i^{\imath}+s-\alpha=0 \\
& i^{\iota}-r-d=0 \\
& r-s=0
\end{aligned}
$$

1. Titik ekuilibrium bebas penyakit

Pada keadaan bebas penyakit, tidak ada individu yang terinfeksi, sehingga $I=0$. Sehingga diperoleh titik ekuilibrium bebas penyakit untuk sistem (5) yaitu:

$$
E_{0}=\left(\frac{r+d}{i}, 0,0\right)
$$

2. Titik ekuilibrium endemic

Pada kondisi endemik ada individu yang terinfeksi maka $I \neq 0$, sehingga diperoleh titik ekuilibrium endemik sebagai berikut:

$$
E^{*}=\left(\frac{r+d}{i},-\frac{\alpha}{d},-\frac{r \iota}{s}\right)
$$

\section{Kestabilan Titik Ekuilibrium}

Untuk mempermudah menentukan kestabilan titik ekuilibrium pada sistem nonlinear, maka sistem nonlinear diubah kedalam sistem linear dengan linearisasi yaitu dengan menentukan matriks jacobian di sekitar titik ekuilibrium.

Didefinisikan fungsi $f(S, I, R)$ sebagai berikut:

$$
f(S, I, R)=\left(\begin{array}{l}
f_{1}(S, I, R) \\
f_{2}(S, I, R) \\
f_{3}(S, I, R)
\end{array}\right) \quad \text { dengan } \quad \begin{aligned}
& f_{1}=-i S I+s R-\alpha N \\
& f_{2}=i S I-r I-d I \\
& f_{3}=r I-s R
\end{aligned}
$$


Matriks jacobian dari sistem persamaan (5) adalah

$$
\begin{aligned}
& I(E)=\left(\begin{array}{lll}
\frac{\partial f_{1}}{\partial S} & \frac{\partial f_{1}}{\partial I} & \frac{\partial f_{1}}{\partial R} \\
\frac{\partial f_{2}}{\partial S} & \frac{\partial f_{2}}{\partial I} & \frac{\partial f_{2}}{\partial R} \\
\frac{\partial f_{3}}{\partial S} & \frac{\partial f_{3}}{\partial I} & \frac{\partial f_{3}}{\partial R}
\end{array}\right) \\
& J(E)=\left(\begin{array}{ccc}
-i i & -i_{i}^{\prime} & S \\
i i & i^{\prime}-r-d & 0 \\
0 & r & -S
\end{array}\right)
\end{aligned}
$$

1. Kestabilan titik ekuilibrium bebas penyakit

Berdasarkan titik ekuilibrium bebas penyakit yaitu $E_{0}$, mensubtitusikan $E_{0}$ ke matriks jacobian (9), sehingga akan diperoleh matriks jacobian dari titik ekuilibrium bebas penyakit sebagai berikut:

$$
J\left(E_{0}\right)=\left(\begin{array}{ccc}
0 & -r-d & s \\
0 & 0 & 0 \\
0 & r & -s
\end{array}\right)
$$

Mencari nilai eigen dari matriks $I\left(E_{0}\right)$ dengan menyelesaikan

$$
\operatorname{det}\left(\lambda-J\left(E_{0}\right)\right)=0
$$

Persamaan karakteristiknya adalah $\lambda(\lambda)(\lambda+s)=0$, Sehingga diperoleh akar-akar dari persamaan karakteristiknya adalah $\lambda_{1}=0, \lambda_{2}=0$ dan $\lambda_{3}=-s$. Berdasarkan nilai eigennya maka kestabilan titik ekuilibrium bebas penyakit adalah stabil.

2. Kestabilan titik ekuilibrium endemik

Berdasarkan titik ekuilibrium endemik yaitu $E^{*}$, mensubtitusikan $E^{*}$ ke matriks jacobian (9), sehingga akan diperoleh matriks jacobian dari titik ekuilibrium endemik sebagai berikut:

$$
J\left(E^{*}\right)=\left(\begin{array}{ccc}
\frac{i \alpha N}{d} & -r-d & s \\
-\frac{i \alpha N}{d} & 0 & 0 \\
0 & r & -s
\end{array}\right)
$$

Mencari nilai eigen dari matriks $I\left(E^{*}\right)$, dengan menyelesaikan

$$
\operatorname{det}\left(\lambda-J\left(E^{*}\right)\right)=0
$$

Persamaan karakteristiknya adalah

$$
d^{3}-i c \lambda^{2}+(s+r+d) \lambda-s i c+2 s i+s i=0
$$

Analisis kestabilan menggunakan kriteria routh-hurtwitz, misalkan:

$$
\begin{aligned}
& a_{0}=d \\
& a_{1}=-i c \\
& a_{2}=s+r \quad+d
\end{aligned}
$$




$$
a_{3}=-s i+2 s 1+s i
$$

Di awal telah didefinisikan bahwa semua parameter bernilai positif, sehingga dapat diketahui nilai $a_{0}>0$, nilai $a_{1}<0$ dan nilai $a_{2}>0$. Sehingga diperoleh tabel routh-hurtwitz sebagai berikut:

\begin{tabular}{|c|c|c|c|}
\hline$\lambda^{3}$ & + & 0 & 0 \\
\hline$\lambda^{2}$ & - & $a_{3}$ & 0 \\
\hline$\lambda^{1}$ & $b_{1}$ & 0 & 0 \\
\hline$\lambda^{0}$ & $c_{1}$ & 0 & 0 \\
\hline
\end{tabular}

Berdasarkan syarat kestabilan dari kriteria routh-hurtwitz tampak bahwa nilai kolom pertama tabel routh-hurtwitz, kolom pertama terdapat nilai positif dan negatif maka sistem tersebut tidak stabil.

Menentukan nilai basic reproduction number (R0)

Nilai basic reproduction number $\left(R_{0}\right)$ dari sistem persamaan (5), dengan metode matriks generasi selanjutnya, diperoleh matrik generasi selanjutya yaitu sebagai berikut:

$$
K=F V^{-1}=[r+d]\left[\frac{1}{r+d}\right]=1
$$

Sehingga diperoleh nilai $R_{O}=\rho K=1$. Menurut Elizabeth $\mathrm{S}$. Allman dan John A. Rodhes, jika $R_{O}=$ 1, maka individu yang sakit hanya menghasilkan satu kasus baru penyakit, dan tidak ada epidemi dapat terjadi, tidak ada pertumbuhan jumlah individu yang terinfeksi.

\section{Model matematika SIRD pada penyebaran virus ebola oleh Peneliti}

Untuk mempermudah dalam pemodelan penyebaran virus ebola ke dalam model matematika diperlukan asumsi-asumsi, yaitu populasi tertutup, individu yang lahir termasuk dalam populasi individu rentan, individu yang sembuh dari ebola tidak diberikan kekebalan, masa inkubasi diabaikan, setiap individu yang terjangkit akan menjadi terinfeksi, kematian alami dan kematian yang disebabkan oleh penyakit lain (selain ebola) terjadi pada populasi individu rentan dan belum ditemukan vaksin.

Berdasarkan keterangan dan asumsi yang ada, dapat dibuat diagram alir model matematika penyebaran virus ebola, sebagai berikut:

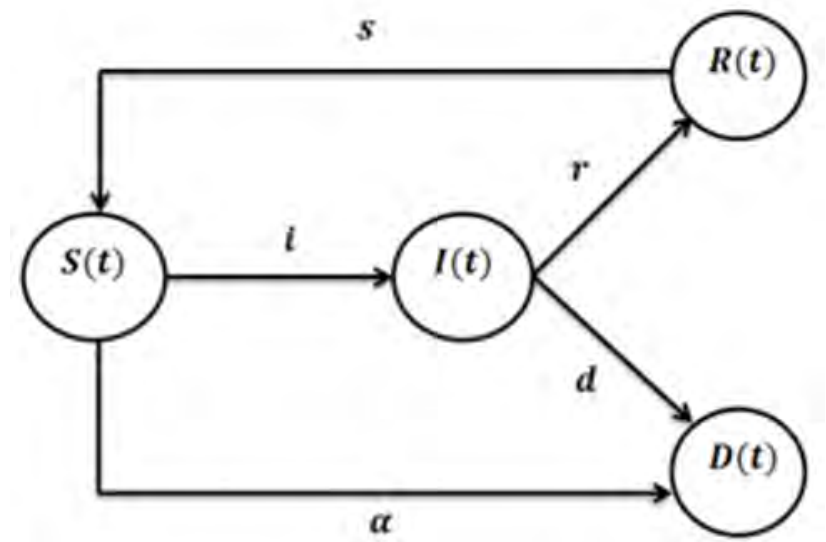

Gambar 2 Diagram alir model SIRD pada penyebaran virus ebola oleh peneliti.

\section{Interpretasi Diagram}

a. Populasi individu rentan

Populasi individu rentan terinfeksi virus ebola, sehingga menjadi populasi individu terinfeksi virus ebola. Populasi individu rentan bertambah karena adanya individu yang sembuh dari ebola, Populasi individu rentan berkurang karena kematian alami dan kematian akibat penyakit selain ebola pada kelas susceptible, sehingga diperoleh persamaaan berikut: 


$$
\frac{d(t)}{d}=-i_{i}^{\prime}(t) l(t)+s(t)-\alpha(t)
$$

b. Populasi individu terinfeksi

Bertambahnya populasi terinfeksi ebola, karena individu yang rentan yang terinfeksi ebola. Berkurangnya populasi individu terinfeksi, dikarenakan individu yang sembuh karena kekebalan tubuh alami dan individu yang mati karena ebola, sehingga diperoleh persamaan berikut:

$$
\frac{d(t)}{d}=i_{i}(t) l(t)-r(t)-d(t)
$$

c. Populasi individu yang sembuh dan tak kebal virus ebola

Populasi ini bertambah dari individu terinfeksi yang sembuh dan berkurang karena individu yang sembuh dari ebola tidak memiliki kekebalan terhadap virus ebola, sehingga akan menjadi individu rentan kembali. Populasi individu yang sembuh dan tidak kebal virus ebola diberikan oleh persamaan berikut:

$$
\frac{d(t)}{d}=r(t)-s(t)
$$

d. Populasi individu yang mati

Populasi individu yang mati disini tidak hanya berasal dari kematian yang disebabkan oleh virus ebola akan tetapi juga kematian yang disebabkan oleh kematian alami dan kematian yang disebabkan oleh penyakit lain (selain ebola) pada kelas susceptibles, sehingga diperoleh persamaan berikut:

$$
\frac{d(t)}{d}=d(t)+\alpha(t)
$$

Dari keempat persamaan diatas diperoleh sistem sebagai berikut:

$$
\begin{aligned}
& \frac{d(t)}{d}=-i^{\prime}(t) I(t)+s(t)-\alpha(t) \\
& \frac{d(t)}{d}=i i^{\prime}(t) I(t)-r(t)-d(t) \\
& \frac{d(t)}{d}=r(t)-s(t) \\
& \frac{d^{2}(t)}{d}=d(t)+\alpha(t)
\end{aligned}
$$

\section{Titik Ekuilibrium}

Dalam keadaan setimbang $\frac{d S}{d t}=0, \frac{d I}{d t}=0, \frac{d R}{d t}=0$, dan $S(t)=S, I(t)=I, R(t)=R$ sehingga persamaan (14) dapat ditulis:

$$
\begin{aligned}
& -i^{\prime}+s-\alpha=0 \\
& i^{`}-r-d=0 \\
& r-s=0
\end{aligned}
$$


1. Titik ekuilibrium bebas penyakit

Pada keadaan bebas penyakit, tidak ada individu yang terinfeksi, sehingga $l=0$. Sehingga diperoleh titik ekuilibrium bebas penyakit untuk sistem (14) yaitu:

$$
E_{0}=\left(\frac{r+d}{i}, 0,0\right)
$$

2. Titik ekuilibrium endemic

Pada kondisi endemik ada individu yang terinfeksi maka $I \neq 0$, sehingga diperoleh titik ekuilibrium endemik sebagai berikut:

$$
E^{*}=\left(\frac{r+d}{i},-\frac{\alpha+\alpha}{i \iota},-\frac{\alpha r^{2}+\alpha}{s_{i}}\right)
$$

\section{Kestabilan Titik Ekuilibrium}

Untuk mempermudah menentukan kestabilan titik ekuilibrium pada sistem nonlinear, maka sistem nonlinear diubah kedalam sistem linear dengan linearisasi yaitu dengan menentukan matriks jacobian di sekitar titik ekuilibrium.

Didefinisikan fungsi $f(S, I, R)$ sebagai berikut:

$$
f(S, I, R)=\left(\begin{array}{l}
f_{1}(S, I, R) \\
f_{2}(S, I, R) \\
f_{3}(S, I, R)
\end{array}\right) \quad \text { dengan } \begin{aligned}
& f_{1}=-i S I+s R-\alpha S \\
& f_{2}=i S I-r I-d I \\
& f_{3}=r I-s R
\end{aligned}
$$

Matriks Jacobian dari sistem persamaan (14) adalah

$$
\begin{aligned}
f(S, l, R) & =\left(\begin{array}{l}
f_{1}(S, l, R) \\
f_{2}(S, l, R) \\
f_{3}(S, l, R)
\end{array}\right) \\
J(E) & =\left(\begin{array}{ccc}
-i,-\alpha & -i_{\llcorner}^{\prime} & s \\
i 1 & i_{i}^{\prime}-r-d & 0 \\
0 & r & -s
\end{array}\right)
\end{aligned}
$$

1. Kestabilan titik ekuilibrium bebas penyakit

Berdasarkan titik ekuilibrium bebas penyakit yaitu $E_{0}$, mensubtitusikan $E_{0}$ ke matriks jacobian (18), sehingga akan diperoleh matriks Jacobian dari titik ekuilibrium bebas penyakit sebagai berikut:

$$
J\left(E_{0}\right)=\left(\begin{array}{ccc}
-\alpha & -r-d & s \\
i 0 & 0 & 0 \\
0 & r & -s
\end{array}\right)
$$

Mencari nilai eigen dari matrikss $J\left(E_{0}\right)$ dengan menyelesaikan:

$$
\operatorname{det}\left(\lambda-J\left(E_{0}\right)\right)=0
$$


Persamaan karakteristiknya adalah $(\lambda+\alpha)(\lambda)(\lambda+s)=0$ sehingga diperoleh akar-akar dari persamaan karakteristiknya adalah $\lambda_{1}=-\alpha, \lambda_{2}=0$ dan $\lambda_{3}=-$ s. Berdasarkan nilai eigennya maka kestabilan titik ekuilibrium bebas penyakit adalah stabil.

2. Kestabilan titik ekuilibrium endemik

Berdasarkan titik ekuilibrium endemik yaitu $E^{*}$, mensubtitusikan $E^{*}$ ke matriks jacobian (18), sehingga akan diperoleh matriks jacobian dari titik ekuilibrium endemik sebagai berikut:

$$
J\left(E^{*}\right)=\left(\begin{array}{ccc}
\frac{\alpha}{d} & r+d & s \\
-\frac{\alpha+\alpha}{d} & 0 & 0 \\
0 & r & -s
\end{array}\right)
$$

Mencari nilai eigen dari matriks $I\left(E^{*}\right)$, dengan menyelesaikan

$$
\operatorname{det}\left(\lambda-J\left(E^{*}\right)\right)=0
$$

Persamaan karakteristiknya adalah

$$
d^{3}-\alpha \lambda^{2}+\left(s_{1}+\alpha r^{2}+r_{1}+\alpha+\alpha\right) \lambda+2 s r^{2}+2 s_{1}+s_{1}=0
$$

Analisis kestabilan menggunakan kriteria routh, misalkan:

$$
\begin{aligned}
& a_{0}=d \\
& a_{1}=-\alpha \\
& a_{2}=s+\alpha r^{2}+r_{1}+\alpha+\alpha \\
& a_{3}=2 s r^{2}+2 s_{1}+s_{1}
\end{aligned}
$$

Di awal telah didefinisikan bahwa semua parameter bernilai positif, sehingga dapat diketahui nilai $a_{0}>0$, nilai $a_{1}<0$, nilai $a_{2}>0$ dan $a_{3}>0$. Sehingga diperoleh tabel routh-hurtwitz sebagai berikut:

\begin{tabular}{|c|c|c|c|}
\hline$\lambda^{3}$ & + & 0 & 0 \\
\hline$\lambda^{2}$ & - & $a_{3}$ & 0 \\
\hline$\lambda^{1}$ & $b_{1}$ & 0 & 0 \\
\hline$\lambda^{0}$ & $c_{1}$ & 0 & 0 \\
\hline
\end{tabular}

Berdasarkan syarat kestabilan dari kriteria routh, tampak bahwa nilai kolom pertama tabel routh-hurtwitz terdapat nilai positif dan negatif maka sistem tersebut tidak stabil.

\section{Menentukan nilai Basic Reproduction Number (R0)}

Nilai basic reproduction number $\left(R_{0}\right)$ dari sistem persamaan (18), dengan metode matriks generasi selanjutnya, diperoleh matrik generasi selanjutya yaitu sebagai berikut:

$$
K=F V^{-1}=[r+d]\left[\frac{1}{r+d}\right]=1
$$

Sehingga diperoleh nilai $R_{O}=\rho K=1$. Menurut Elizabeth $\mathrm{S}$. Allman dan John A. Rodhes, jika $R_{O}=$ 1, maka individu yang sakit hanya menghasilkan satu kasus baru penyakit, dan tidak ada epidemi dapat terjadi, tidak ada pertumbuhan jumlah individu yang terinfeksi. 


\section{Simulasi Model}

Simulasi model menggunakan software Matlab versi 6.1.0.450 plot populasi $S, I, R$ dan $D$, terhadap waktu. Adapun nilai parameter yang digunakan yaitu $\alpha=0,01 ; s=0,02 ; i=0,01 ; r=0,04, d=$ 0,06 , dengan nilai awal yaitu $S(0)=900 ; l(0)=100 ; R(0)=0$ dan $D(0)=0$. Berikut adalah simulasi model matematika $S$ pada penyebaran virus ebola.

1. Simulasi model matematika SIRD pada penyebaran virus ebola oleh Abdon A. dan Emile F. D. G.

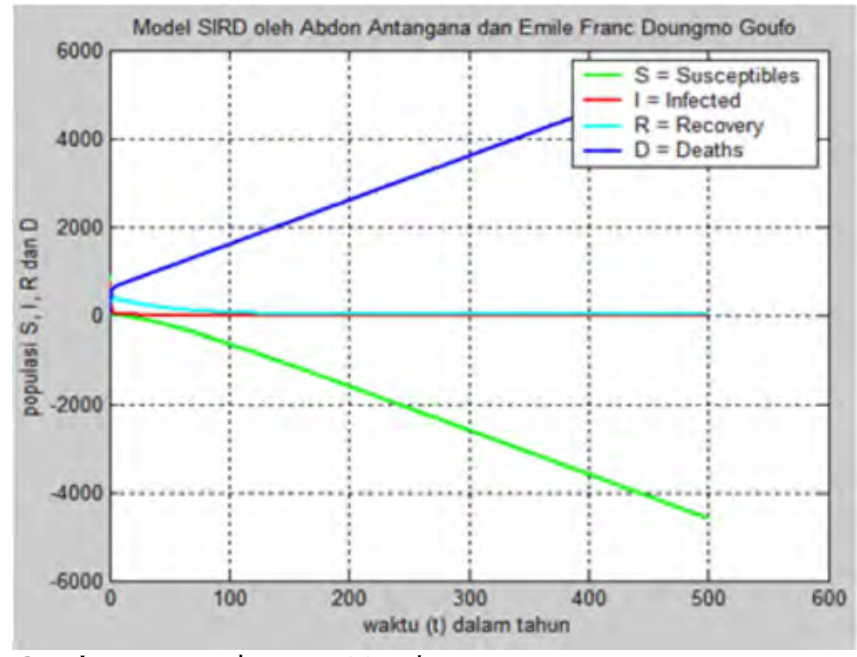

Gambar 3 Untuk $t<500$ tahun
Gambar 3 menunjukkan perubahan jumlah populasi $S, I, R$ dan $D$ terhadap waktu. Terlihat bahwa dalam waktu $t<1$ tahun populasi $S$, seluruhnya terinfeksi virus ebola. Populasi $I$ dan populasi $R$ turun mendekati nol dan seiring berjalannya waktu populasi $S$ dan populasi $I$ akan habis. Populasi $D$ dari tahun ketahu semakin meningkat dan populasi $N$ akan habis dalam waktu $t<100$ tahun.

2. Simulasi model matematika SIRD pada penyebaran virus ebola oleh peneliti

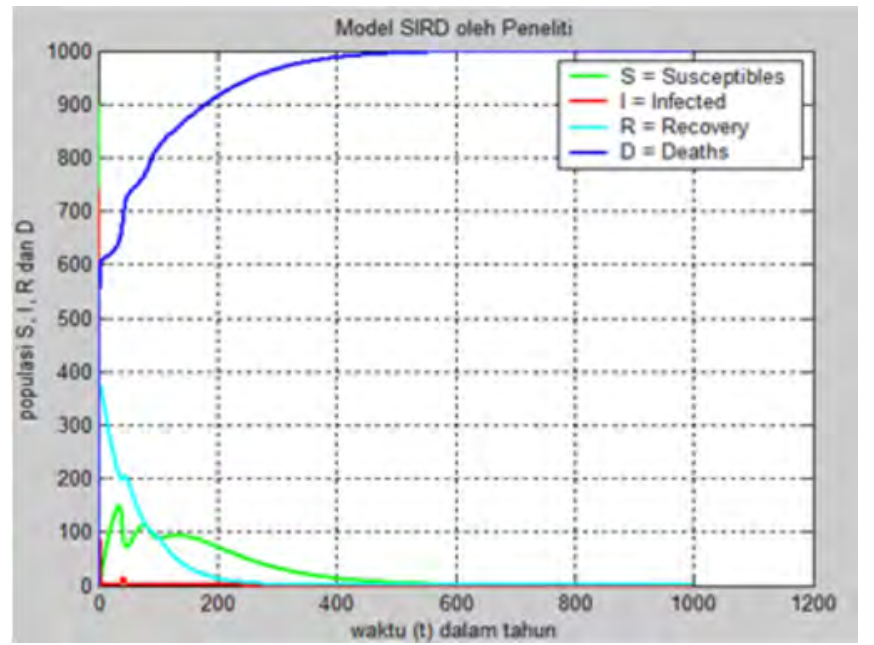

Gambar 4 Untuk $t<1000$ tahun
Gambar 4 menunjukkan perubahan jumlah populasi $S, I, R$ dan $D$ terhadap waktu. Terlihat bahwa dalam waktu $t>200$ tahun populasi $S$, I dan $R$ menuju nol, seiring dengan berjalannya waktu maka populasi $S$, I dan $R$ akan habis, Populasi $D$ dari tahun ketahun semakin meningkat dan dalam waktu $t<500$ tahun, populasi total $N$ akan habis.

\section{Kesimpulan}

Berdasarkan hasil analisis dan simulasi model matematika SIRD pada penyebaran virus ebola, diperoleh kesimpulan dan saran sebagai berikut:

1. Model matematika SIRD pada penyebaran virus ebola yaitu:

a. Model matematika SIRD pada penyebaran virus Ebola oleh Abdon A. dan Emile F. D. G. 


$$
\begin{aligned}
& \frac{d S(t)}{d t}=-i S(t) I(t)+s R(t)-\alpha N \\
& \frac{d I(t)}{d t}=i S(t) I(t)-r I(t)-d I(t) \\
& \frac{d R(t)}{d t}=r I(t)-s R(t) \\
& \frac{d D(t)}{d t}=d I(t)+\alpha N
\end{aligned}
$$

dengan asumsi kematian alami dan kematian oleh penyakit selain ebola terjadi pada populasi total $N$ di populasi individu rentan.

b. Model matematika SIRD pada penyebaran virus ebola oleh peneliti

$$
\begin{aligned}
& \frac{d S(t)}{d t}=-i S(t) I(t)+s R(t)-\alpha S(t) \\
& \frac{d I(t)}{d t}=i S(t) I(t)-r I(t)-d I(t) \\
& \frac{d R(t)}{d t}=r I(t)-s R(t) \\
& \frac{d D(t)}{d t}=d I(t)+\alpha S(t)
\end{aligned}
$$

dengan asumsi kematian alami dan kematian yang disebabkan oleh penyakit selain ebola hanya terjadi pada populasi individu rentan.

2. Diperoleh dua titik ekuilibrium dari kedua model matematika SIRD pada penyebaran virus ebola yaitu:

a. Titik ekuilibrium bebas penyakit yang sama yaitu $E_{0}=\left(\frac{r+d}{i}, 0,0\right)$ dengan kestabilan kedua titik yang berbeda.

b. Titik ekuilibrium endemik yang berbeda yaitu: $E^{*}=\left(\frac{r+d}{i},-\frac{\alpha}{d},-\frac{r}{s}\right)$ oleh model Abdon A. dan Emile F. D. G dan $E^{*}=\left(\frac{r+d}{i},-\frac{\alpha+\alpha d}{i_{1}},-\frac{\alpha r^{\bar{z}}+\alpha}{s}\right)$ oleh model peneliti, dengan kestabilan kedua titik yang tidak stabil.

3. Diperoleh nilai basic reproduction number $(R O)$ yang sama dari kedua model yaitu $R O=1$. Jika $R O$ $=1$, maka individu yang sakit hanya menghasilkan satu kasus baru penyakit, tidak terjadi epidemi dan tidak ada pertumbuhan jumlah individu yang terinfeksi virus ebola.

4. Jadi dari simulasi kedua model, dapat diketahui bahwa model penyebaran virus ebola oleh Abdon A. dan Emile F. D. G. lebih valid dari pada model oleh peneliti pada model matematika SIRD, dikarenakan virus ebola hanya butuh waktu $t<50$ tahun untuk menghabiskan populasi total $N$.

\section{Referensi}

[1] Allman, Elizabeth S. dan John A. Rodhes. 2003. Mathematical Models in Biology. Cambridge University Press: New York.

[2] Antangana, Abdon dan Goufo, Emile F. D. 2014. On the Mathematical Analysis of Ebola Hemorrhagic Fever: Deathly Infection Disease in West African Countries. Institute for Groundwater Studies and University of South Africa: South Africa.

[3] Anton, H. 1987. Aljabar Linear Elementer. (Alih Bahasa: Pantur Silaban). Erlangga: Jakarta.

[4] Driessche, P. Van den dan Watmough, J. 2002. Jurnal: Reproduction Numbers and Subthreshold Endemic Equilibria for Compartmental Models of Disease Transmission. University of Victoria and University of New Brunswick: Canada. 
[5] Jayanti, Nita, Nurul Ulfah dan Tyan Retsa. 2014. Jurnal: Model Transmisi Penyakit Demam Berdarah Dengue. Universitas Negeri Jakarta: Jakarta.

[6] Olsder, G. J dan J. W. van der Woude. 2004. Mathematical System Theory. Deflt Univercity of Technology: Belanda.

[7] Perko, Lawrence. 2001. Differential Equations and Dynamical Systems. Springer-Verlag: New York.

[8] Ross, Shepley. L. 1984. Introduction to Ordinary Differential Equations. John Wiley and Sons: USA.

[9] Widowati dan Sutimin. 2007. Buku Ajar Pemodelan Matematika. Universitas Diponegoro: Semarang.

[10] Triwiyatno, Aris. 2011. Buku Ajar Sistem Kontrol Analog. Universitas Diponegoro: Semarang (http://aristriwiyatno.blog.undip.ac.id/files/2011/10/Bab-3-Analisa-Kesta- bilan1.pdf).

[11] Yarus, Zach. 2012. A Mathematical Look at the Ebola Virus. 